\title{
Nuwe waardering vir Luther in die gereformeerde etiek
}

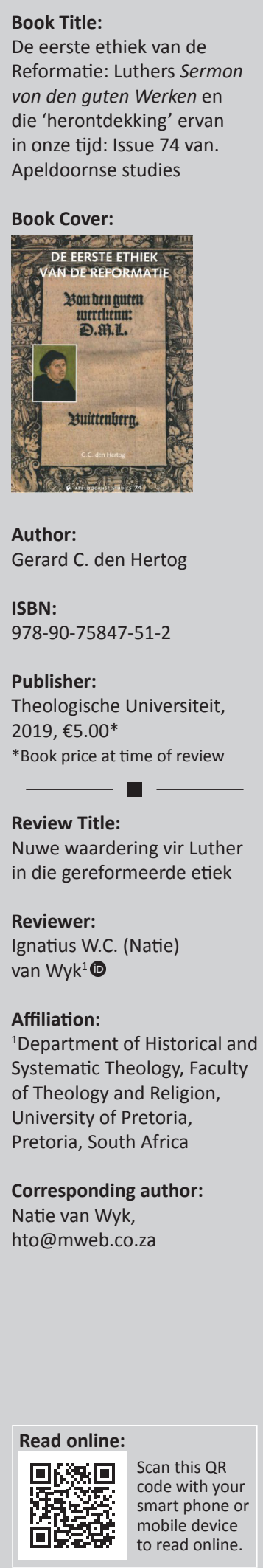

Ons het in hierdie publikasie met prof. dr. G.C. den Hertog (gebore 1949) se afskeidsrede, in 'n uitgebreide weergawe, te make. Hy was hoogleraar in Sistematiese Teologie aan die Teologiese Universiteit te Apeldoorn, Nederland. As gereformeerde etikus, gryp hy aan die einde van sy akademiese loopbaan aan die Universiteit terug na Martin Luther. Hy keer met ander woorde terug na die oorsprong van Reformatoriese etiek - en wel na Luther se publikasie Oor die goeie werke (1520). Die outeur verklap niks oor die persoonlike redes vir sy keuse nie. Die teologiese belangrikheid van Luther se geskrif was seker rede genoeg vir die keuse. Dit bly egter merkwaardig (en verblydend) dat die geleerde Van Apeldoorn sy loopbaan (voorlopig) met Luther afgesluit het. Verdere publikasies oor Luther sal in die Afrikaanssprekende gemeenskappe verwelkom word.

Die boek bestaan uit vyf hoofstukke. Die inleidende eerste hoofstuk handel oor die agtergrond van Luther se geskrif, die vraag of ons hiermee met die eerste Protestantse etiek te make het, en die verduideliking van die aanpak van die boek. Den Hertog verduidelik dat Luther se geskrif nie volgens huidige maatstawwe as 'n etiekhandboek gereken kan word nie, maar dat dit in maklik verstaanbare taal en argumentvoering helderheid verskaf oor die wil van God soos te vinde is in die dekaloog. Dat hierdie geskrif van 1520 'n belangrike grondpilaar van Luther se teologie sou vorm, word grondig verduidelik.

Hoofstuk twee behandel die opbou en inhoud van Luther se geskrif en die outeur kom tot 'n voorlopige bevinding. Hy konsentreer hoofsaaklik op Luther se uitleg van die eerste gebod (die uitvoerigste gedeelte van die geskrif). Den Hertog sluit in sy eie nadenke oor etiek juis hierby aan. Sonder geloof en vertroue in die lewende en handelende God, maak die teoloog geen unieke bydrae tot die lewe nie. Luther se uitleg van die dekaloog binne die gemeentelike liturgie en die uitgebreide liturgiese kalender, word ook deur Den Hertog in eensgesindheid beklemtoon. Die verlore band tussen liturgie en etiek vandag is 'n belangrike rede waarom Christelike etici nie meer ernstig opgeneem word nie.

In hoofstuk drie word 'n belangrike, maar verwaarloosde uitdrukking van Luther se teologiese etiek verduidelik, naamlik die vita passiva. Die kern van Luther se argument is dat geloof nooit sonder denke en handelinge is nie. God kom ons handelend en denkend teë. Hy betrek ons in sy herskeppende en vernuwende werk in Christus deur aan ons genade en barmhartigheid te betoon. Regverdiging kan daarom by Luther nie slegs as 'n forensiese daad verstaan word nie, maar ook as 'n daad van morele belang. Goeie werke is daarom God se werke wat Hy verrig deur mense wat Hy met sy liefde aanraak. God se skeppende geregtigheid is vanselfsprekend van belang vir die Christelike etiek.

Hoofstuk vier behandel die 'herontdekking' van Luther se oorspronklike waardering van die goeie werke in die twintigste eeu. Daar word aan Paul Althaus (1888-1966), Dietrich Bonhoeffer (1906-1945) en Hans Günter Ulrich (1942-) aandag gegee. Althaus en Bonhoeffer word bespreek teen die agtergrond van die verkeerde ontwikkelings in die Lutherse etiek. Ulrich, wat waarskynlik in Suid-Afrika onbekend is (ek het hom gelukkig in 1983 in Gerhard Sauter se doktorale seminare leer ken), is 'n gerespekteerde interpreteerder van Luther se sosiale etiek. Sy belangrike bydrae het met 'n nuwe koppeling tussen etiek en die gemeentelike erediens te make. In 'n tyd waarin die 'missionale teologie' juis die band tussen 'koninkryk-etiek' en die kerklike erediens verwater, is dit belangrik dat die stem van Ulrich ook in Suid-Afrika gehoor word.

In die laaste hoofstuk gee die outeur sy eie mening oor Luther se geskrif en dui 'n koers vir die toekoms aan. Naas die impulse uit Luther se vita activa en Ulrich se beklemtoning van die erediens,

How to cite this book review: Van Wyk, I.W.C., 2019, 'Nuwe waardering vir Luther in die gereformeerde etiek', In die Skriflig 53(1), a2531. https://doi.org/10.4102/ids.v53i1.2531

Copyright: ( 2019. The Authors. Licensee: AOSIS. This work is licensed under the Creative Commons Attribution License. 
konsentreer Den Hertog ook nog op die motief van die vreugde van die wet.

In tye van disoriëntasie is dit goed om na die oorspronge van die eie geloofstradisie terug te keer. Den Hertog se teruggryp na die 'eerste Protestantse etiek' is van groot waarde vir die Afrikaanse gemeenskappe. Die 'vermoralisering' van ons godsdienstige lewe en nadenke doen groot skade aan die evangelie van Jesus Christus en die welwese van die samelewing. Wat tans nodig is, is gehoorsaamheid aan die wet van God. Gehoorsaamheid sal slegs dán gedy wanneer die openbare diskoers oor moraliteit en etiek weer by die basiese geloofsuitsprake van die Nuwe Testament, en dus ook die Reformasie, aansluit. Den Hertog se boek kan hiermee help.

Hierdie boek getuig van deeglike navorsing. Dit is egter maklik leesbaar - selfs deur nie-teoloë. Diegene wat nie die enkele Duitse aanhalings kan verstaan nie, sal wel uit die konteks agterkom wat Luther wou sê. Hierdie publikasie word van harte aanbeveel. 